\title{
Climatic Variations and Cereal Production in India: An Empirical Analysis
}

\author{
Prof. (Dr.) Surender Singh
}

Professor, Department of Economics, BPS Women University, Haryana, India

\begin{abstract}
The study is an attempt to forecast the impact of climate variations on the production of two main cereal crops, i.e., wheat and paddy, by employing a crop model using cross-section data for the year 2014-2015. The findings predict that the yield of the wheat crop is expected to go down in the farms in the plains by 10.11 per cent, while set to increase in the farms in the hills by 6.70 per cent, respectively by 2100 AD. The results, further pinpoint that the production of paddy crop is expected to decline in both farms in the plains and farms at hills by 15.04 percent and 12.83 per cent respectively for farms in the plains and farms in the hills by the turn of this century. The study recommends the expansion of area under wheat cultivation for the farms in the hills in order to compensate the loss in production of wheat farming in farms in the plains to maintain the aggregate production of wheat at the same level. There found a dire need for the development and adoption of climate responsive varieties of both crops along with the spatial diversification of crops (full or partial), to cope with the future shocks of climate variability.
\end{abstract}

Keywords-Climate Change, Crop Model, Paddy, Rainfall, Temperature, Wheat.

\section{INTRODUCTION}

Climate change denotes a long-term change in the Earth's climate, especially a change due to an increase in the mean atmospheric temperature. Climate change refers to the rise in average surface temperatures on Earth mainly due to the burning of fossil fuels, besides other human activities, such as agriculture, transportation, deforestation, etc., which releases carbon dioxide and other greenhouse gases into the atmosphere [19]. World's food security and efforts for sustainable development are under threat by the ongoing process of climate alteration. It denotes a change of climate that alters the composition of the global atmosphere that is attributed directly or indirectly to human activity and that is in addition to natural climate variability observed over comparable time periods [7]. Climate change results in increased global mean temperature which affect rainfall frequency, thereby, influence the agricultural development of countries. The combined effects of higher temperature and rainfall along with their greater variability lead to more frequent and intense droughts, floods, and reduced availability of water for irrigation can be devastating for agriculture sector especially in tropical regions. A rise in global temperature $1.5-3.2^{\circ} \mathrm{C}$ may lead to a significant fall in the production of cereal crops in tropical and subtropical regions. Agriculture in many developed countries may be promoted by warming of less than the $2{ }^{\circ} \mathrm{C}$ global mean temperature in the mid and high latitudes. Nevertheless, the global disparities will increase, as the gains are expected in the developed world and the losses in developing countries [22]. The effects of climatic change in the agriculture sector are very complex to interpret as it casts differentiated effects on different crops and in different areas. The world has already perceived that the Sahel, the Mediterranean, Southern Africa, has become wetter whereas many South Asian countries are becoming drier. The process of climate change, initiating a change in temperature and precipitation, affects soil moisture, soil content, the timing of sowing and/or harvesting and the length of growing seasons. Agricultural crop production is affected by biophysically effects which induces fluctuations in temperatures, precipitation level and $\mathrm{CO}_{2}$, and the socioeconomic factors contributing to price changes and a shift in comparative advantages. The climate change is going to benefit countries in middle and higher latitudes owing to lengthening of growing seasons and expansion in cropproducing areas poleward [16]. The higher temperature in the tropics can be expected to reduce the yields of the primary food crops and will also dry up soil moisture leading to further decline in yields up to 30 percent [6]. Growing $\mathrm{CO}_{2}$ concentrations in the atmosphere are responsible for an accelerated rate of water use by flora owing to increased rate of photosynthesis that is more robust for plants with the C3 photosynthetic pathway (crop like wheat, paddy, soyabean etc.) as compared to other categories of plants.

Existing literature related to the assessment of the future impact of climatic change on agriculture sector reveals both pessimism and optimism across the world. Newman [13] concludes that the 'corn-belt' in the United States would shift North-East for every $1^{\circ} \mathrm{C}$ rise in temperature. 
The climate change would increase winter wheat production in Canada, and regional shifts in wheat cultivators in the United States [17]. Parry and Knoijin[14] highlight that warmer temperature in highlatitude countries will by the lengthening of the growing season increase crop production without taking into account $\mathrm{CO}_{2}$ effects or adaptation. Adams et al. [1] examined the impact of climate change using agroeconomic models for the United States and showed that the net acreage sown will increase with the severity of climate change which will lead to a net gain of US \$910.8 billion. Environment Protection Agency [5] forecast, for the year 2060, that global mean temperature will increase by $4^{\circ} \mathrm{C}$ to $5.2^{\circ} \mathrm{C}$ and the yield of soya beans, wheat and rice may drop by 21 per cent, 17 per cent and 6 per cent respectively. Darwin et al. [13] forecast the impacts of climate change on United States agriculture will range from US $\$-4.8$ billion to US $\$ 5.8$ billion. The finding further pinpoints that due to the lengthening of the growing season the new land class will increase by 38.9 per cent to 55.3 per cent on the one hand and pasture land will increase by 0.7 per cent to 7.4 per cent on the other hand. The climate change will increase the area under arable land in agricultural beside a positive swing towards the production of the wheat crop. Reilly, John [15] pinpoints that a doubling of carbon dioxide concentrations would lead to yield improvement that ranges from 10 per cent to 30 per cent. Murdiyarso[12] estimates the potential impact of climate change and variability on rice production in Asia and forecast a 7.4 per cent decline in the production of rice per degree increase in temperature. Further, increased temperature will pressurise the farmers to use the less fertile land for agriculture, thereby depressing production.

The research pertaining to India resembles that a $2^{\circ} \mathrm{C}$ increase in mean air temperature could cut the rice yield by 0.75 tonnes per hectare and a $1^{\circ} \mathrm{C}$ temperature in winter temperature leads to 10 per cent reduction in wheat production in Punjab, Haryana and Uttar Pradesh [21]. Rosenzweig and Parry [17] found that a rise in temperature of $4^{\circ} \mathrm{C}$ could result in grain yields in India reducing by 25-40 per cent. Kumar and Parikh [9] predicted 30-35 percent reduction in rice yields for India. Mendelsohn et al. [11] forecasted a reduction in the agricultural output without carbon fertilization by 60.9 percent for the North-East region, 57.9 per cent for the Northwest region, 31.3 per cent for the South-East region and 36.8 per cent for the South-West region in their study for 2080 using data for 20 year period (1966-86). Singh [20] predicted that the production of the rice crop is expected to decline by 12.35 per cent and that of wheat crop by 17.45 per cent by the year 2100 in the event of a $3^{\circ} \mathrm{C}$ of warming. The findings reflect that increase in $1^{\circ} \mathrm{C}$ temperature (without an increase in rainfall) is more adverse than the increase in $2^{\circ} \mathrm{C}$ temperature when accompanied by a $10 \mathrm{~mm}$ increase in rainfall in the production of food crops.

Agriculture sector still remains the mainstay of the Indian economy as it provides employment to 48.9 percent of people, despite the continued decline in its share, i.e., from 57.7 percent (1950-51) to 17.4 percent of GDP [4]. The total food grain production is estimated to be 252.23 million tonnes in 2015-16 as compared to 196.81 tonnes in 2000-01. The area under cultivation and yield of wheat and rice crops has reached near saturation since 2000-01 (Singh, 2017). The agricultural crop production in India is under pressure as many global reports[5,6] and research $[9,11,21,20]$ predicts a substantial fall in cereal production by the year 2060 and so on. Therefore, in this background, the present study is an attempt to map the future impact of the climatic change on wheat and paddy in India by capturing its impact on farms in the plains as well as farms at hills separately for both crops and intends to test the following hypotheses:

$>$ The climate change does not affect the wheat and paddy production; and

$>$ The impact of climate change is indifferent to farms at plains or hills.

\section{MATERIAL AND METHODS}

The crop model

The crop model has conventionally been used for measuring the impact of climate change in the production of crops in agricultural sector across the world. The crop model is based production function analysis and is estimated by taking into account environmental variables such as temperature, rainfall and carbon dioxide as inputs into the production of crops. Mendelsohn et al. (1994) used crop model for measuring the relationship between agricultural production and climate change in order to analyse the impacts of climate change on agriculture. The estimated production function measures the changes in yield prompted by changes in environmental variables [1, $2,8]$. This model predicts more reliably the way climate affects yield because the impact of climate change on crop yields is determined through controlled experiments. The crop model, specified in terms of output as dependent variable and temperature and rainfall as independent variables, is given below:

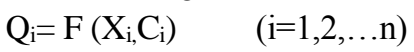

Where $Q=$ Output (per unit of land)

$X_{i}=\left(X_{1 j \ldots}, X_{i j \ldots} X_{i j}\right)$ is a vector of purchased inputs for $i^{\text {th }}$ crop; 
$X_{i j}$ is purchased input $j(J=1,, j)$ in the production of $i^{\text {th }}$ crop; and

$\mathrm{C}_{\mathrm{i}}=\left(\mathrm{C}_{1 \ldots, \ldots} \mathrm{C}_{\mathrm{m}} \ldots \mathrm{C}_{\mathrm{m}}\right)$ is a vector of environmental variables like temperature, rainfall etc.

IPCC [7] in its fourth report, keeping in view the linear trend of warming of the $20^{\text {th }}$ century, predicted that the global average surface temperature is set to increase by $3^{\circ} \mathrm{C}$, i.e., $0.2^{\circ} \mathrm{C}$ per decade, by $2100 \mathrm{AD}$, which in turn may increase the rainfall activity up to 15 per cent. Accordingly, the present study forecast the future impacts of climate change by setting a trend of $0.24^{\circ} \mathrm{C}$ per decade till $2100 \mathrm{AD}$ and visualize the four climate projections, i.e., Projection I (Base year, 2014-15), Projection II (for the year 2020) Projection III (for the year 2060) and Projection IV (for the year 2100). The temperature in projection II, projection III and Projection IV is increased by $1^{\circ} \mathrm{C}, 2^{\circ} \mathrm{C}$ and $3^{\circ} \mathrm{C}$ respectively, whereas the rainfall has been increased by 0 per cent, 10 per cent, and 15 per cent respectively for projection II, projection III and projection IV, respectively. There will be a new climate model for each category of farms under investigation, for each climate projection [20]. For each climatic projection, the climate models predicted change in the baseline temperature in all individual categories of farms. The impact of climatic change is measured by the change in crop production (US \$) resulting from a climate change from $C_{b}$ (baseline) to $C_{n}$ can be measured as:

$\Delta \mathrm{Q}=\mathrm{Q}\left(\mathrm{C}_{\mathrm{b}}\right)-\mathrm{Q}\left(\mathrm{C}_{\mathrm{n}}\right)$

By comparing the crop yield under different locations/ different climatic projections, the actual response of crop yield can be estimated as:

$\mathrm{Q}_{\mathrm{i}}=\mathrm{F}\left(\mathrm{C}_{\mathrm{i}}\right)+\mathrm{U}_{\mathrm{i}}$

Where

$\mathrm{Q}$ is the expected production for $\mathrm{i}^{\text {th }}$ crop;

$\mathrm{C}_{\mathrm{i}}$ is the exogenous environmental variables and;

$\mathrm{U}_{\mathrm{i}}$ is the error term.

The crop model used in the present study is as under:

$\mathrm{Q}=\alpha_{0}+\alpha_{1} \mathrm{X}_{1}+\alpha_{2} \mathrm{X}_{2}+\alpha_{3} \mathrm{X}_{3}+\alpha_{4} \mathrm{X}_{4}+\alpha_{5} \mathrm{X}_{5}+\mathrm{U}_{\mathrm{i}}$

Where

$\mathrm{Q}=$ Value of output (US \$ per hectare)

$\mathrm{X}_{1}=$ Schooling (years)

$\mathrm{X}_{2}=$ Temperature in summer (Degree Celsius)

$\mathrm{X}_{3}=$ Temperature in winter (Degree Celsius)

$\mathrm{X}_{4}=$ Rainfall in winter $(\mathrm{mm})$

$\mathrm{X}_{5}=$ Rainfall in summer $(\mathrm{mm})$

$\mathrm{U}=$ Error Term

$\alpha$ 's $=$ Parameters to be estimated

The Database

A multi-stage random sampling technique has been employed in the study. In the first stage of sampling four cereals producing states of India, i.e., Haryana, Punjab, Himachal Pradesh, and Uttrakhand, have been selected randomly. The former two represent belong to the farms in the plains, whereas the latter two from the category of farms in the hills. In the second stage of sampling, five districts from each of the selected states have been selected. The third stage of sampling marked with the selection of two villages from each of the sampled districts, whereas as the final stage of sampling is characterized by selection of 20 farms from each of the selected villages randomly. Resultantly, a sample of 800 farms, i.e., 400 farms from the plains and 400 farms from the hills is selected for the purpose. Data on principal crops for the year 2014-2015 pertaining to their total production, cost and inputs used were collected through a pre-tested survey schedule from the sampled farm, whereas, the data relating to temperature, rainfall and precipitation have been compiled from the database of the Indian Meteorological Department, Pune (India).

\section{RESULTS AND DISCUSSION}

A brief description of variables used in the study along with the parameter estimates of multiple regression models are presented in this section.

Basic statistics of variables

Table 1 displays some key features of the sampled farms related to the area, output and cost of production of wheat and paddy crops in the plains as well as in the hills in India that are vital in the assessment of the impact of the climate change in the production. The value of output per hectare for both crops is almost twice for the farms in the plains as compared to farms in the hills, while the output per man days per acre for both crops is comprehensively higher in the farms in plains as compared to farms in the hills. The farms at hills have been found employing more labour per hectare in the case of both crops. The size of the farm holdings in farms at plains is thrice the farm size at hills, whereas the schooling of the farm managers turned out twice that of farms in the hills.

Table 2 highlights the key cost of production statistics related to the production of wheat and paddy crop in the farms at hills and in the plains. The capital cost, investment in agricultural machinery \& equipment and investment in irrigation facilities have been found considerably higher in the farms in the plains as compared to farms in the hills. Similarly, the expenditure (per hectare) on chemical fertilisers, pesticides \& Insecticides and irrigation cost turned out to be comprehensively higher in the farms in the plains as compared to farms in the hills.

The number of tube wells came out to be 0.41 and 0.07 per acre in the plains and hills respectively. The average temperature of sampled farms both in the plains and hills is almost similar, while the amount of rainfall is almost 
thrice the farms in the hills as compared to farms at plains. In nutshell, the sample features of farms on the hills and plains disclose that the farms in the plains are enjoying much better resources (except rainfall) facilities as compared to farms in the hills.

Table.1: Basic Statistics pertaining to area and output used in the study

\begin{tabular}{|c|c|c|}
\hline \multicolumn{2}{|l|}{ Variables } & Values \\
\hline Total Cultivated Area (hectares) & $\begin{array}{l}\text { Plains } \\
\text { Hills }\end{array}$ & $\begin{array}{c}1026.31 \\
477.54 \\
\end{array}$ \\
\hline 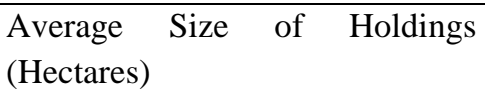 & $\begin{array}{l}\text { Plains } \\
\text { Hills }\end{array}$ & $\begin{array}{l}2.57 \\
1.19\end{array}$ \\
\hline $\begin{array}{l}\text { Output (US \$ } \quad \text { per hectare) } \\
\text { Wheat Crop }\end{array}$ & $\begin{array}{l}\text { Plains } \\
\text { Hills }\end{array}$ & $\begin{array}{l}822.75 \\
368.13\end{array}$ \\
\hline $\begin{array}{l}\text { Output (US \$ } \quad \text { per } \text { hectare) } \\
\text { Paddy Crop }\end{array}$ & $\begin{array}{l}\text { Plains } \\
\text { Hills }\end{array}$ & $\begin{array}{l}910.30 \\
483.87\end{array}$ \\
\hline $\begin{array}{l}\text { Labour Man days (per hectare) } \\
\text { Wheat Crop }\end{array}$ & $\begin{array}{l}\text { Plains } \\
\text { Hills }\end{array}$ & $\begin{array}{l}11.49 \\
16.51\end{array}$ \\
\hline $\begin{array}{l}\text { Labour Man days (per hectare) } \\
\text { Paddy Crop }\end{array}$ & $\begin{array}{l}\text { Plains } \\
\text { Hills }\end{array}$ & $\begin{array}{l}34.00 \\
44.02\end{array}$ \\
\hline $\begin{array}{l}\text { Output per } \quad \text { man-days } \\
\text { Wheat Crop (US \$ }\end{array}$ & $\begin{array}{l}\text { Plains } \\
\text { Hills }\end{array}$ & $\begin{array}{l}71.61 \\
22.30\end{array}$ \\
\hline 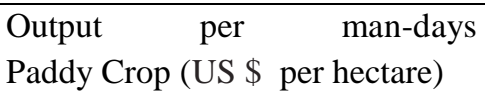 & $\begin{array}{l}\text { Plains } \\
\text { Hills }\end{array}$ & $\begin{array}{l}26.77 \\
11.03\end{array}$ \\
\hline $\begin{array}{l}\text { Average Years of Schooling of } \\
\text { Manager (years) }\end{array}$ & $\begin{array}{l}\text { Plains } \\
\text { Hills }\end{array}$ & $\begin{array}{l}9.5 \\
5.5\end{array}$ \\
\hline
\end{tabular}

Estimation of crop model for paddy farms

The parameter estimates of the crop model for a sample of 366 paddy farms in the plains are presented in table 3. The F-statistics for all the four models estimated have been found statistically significant while the variable schooling is found insignificant in all four projections. Further, as indicated by Table 3 , the coefficients for summer temperature and rainfall in summer have been found statistically significant at 5 per cent level of significance in all four projections. However, the coefficient of summer temperature is found to have a negative sign.

Table.2: Basic Statistics pertaining to cost of production used in the study

\begin{tabular}{|l|l|l|}
\hline \multicolumn{2}{|l|}{ Variables } & Values \\
\hline Capital Cost & Plains & 69.31 \\
(US \$ per hectare) & Hills & 55.68 \\
\hline Chemical Fertilizers & Plains & 114.53 \\
(US \$ per hectare) & Hills & 65.94 \\
\hline Pesticides \&Insecticides & Plains & 65.39 \\
(US \$ per hectare) & Hills & 22.93 \\
\hline Irrigation Cost & Plains & 129.30 \\
(US \$ per hectare) & Hills & 51.71 \\
\hline Agricultural Machinery and & Plains & 181.13 \\
Equipment & Hills & 98.32 \\
(US \$ per hectare) & & \\
\hline No. of Tubewells & Plains & 0.41 \\
(Per hectare) & Hills & 0.07 \\
\hline Investment in Irrigational & Plains & 267.26 \\
Facilities & Hills & 107.80 \\
(US \$ per hectare) & & \\
\hline Average Annual & Plains & 25.54 \\
Temperature ( ${ }^{0}$ C) & Hills & 23.33 \\
\hline Average Annual Rainfall & Plains & 200.04 \\
(mm) & Hills & 669.11 \\
\hline
\end{tabular}

Table.3: Parameter estimates of crop model for paddy for farms in plains

\begin{tabular}{|l|c|c|c|c|}
\hline Variables & $\begin{array}{c}\text { Coefficients } \\
\text { Projection I }\end{array}$ & $\begin{array}{c}\text { Coefficients } \\
\text { Projection II }\end{array}$ & $\begin{array}{c}\text { Coefficients } \\
\text { Projection III }\end{array}$ & $\begin{array}{c}\text { Coefficients } \\
\text { Projection IV }\end{array}$ \\
\hline Intercept & 13812.8 & 14235.20 & 14958.32 & 15302.16 \\
& $(6663.88)$ & $(6698.56)$ & $(6723.59)$ & $-6895.20)$ \\
\hline Schooling & -128.09 & -128.09 & -128.09 & -128.09 \\
& $-(179.85)$ & $-(179.85)$ & $-(179.85)$ & $-(179.85)$ \\
\hline Temperature summer & $-173.36^{*}$ & $-173.36^{*}$ & $-173.36^{*}$ & $-173.36^{*}$ \\
& $-(73.65)$ & $-(73.65)$ & $-(73.65)$ & $-(73.65)$ \\
\hline Temperature winter & -4121.49 & -4236.65 & -4365.23 & -4569.28 \\
& $-(3125.20)$ & $-(3235.40)$ & $-(3298.26)$ & $-(3301.21)$ \\
\hline Rainfall winter & 277.74 & 277.74 & 277.74 & 277.74 \\
& $(508.96)$ & $(508.96)$ & $(508.96)$ & $(508.96)$ \\
\hline Rainfall summer & $25.58^{*}$ & $25.58^{*}$ & $25.58^{*}$ & $25.58^{*}$ \\
& $(13.52)$ & $(13.52)$ & $(13.52)$ & $(13.52)$ \\
\hline F- Value & $17.13^{*}$ & $16.17^{*}$ & $16.83^{*}$ & $15.87^{*}$ \\
\hline Adjusted R & 0.26 & 0.26 & 0.26 & 0.26 \\
\hline N & 366 & 366 & 366 & 366 \\
\hline
\end{tabular}

Note:*Significant at 5 per cent level of Significance.

Figures in the parenthesis represent standard errors 
Table 4 highlights the parameter estimates of the crop model for a sample of 254 paddy farms in the hills which again shows that the coefficients for summer temperature and rainfall in summer have been found statistically significant at 5 per cent level of significance in all four projections. However, the coefficient of summer temperature is found to have a negative sign.

Table.4: Parameter estimates of crop model for paddy farms for hills

\begin{tabular}{|l|c|c|c|c|}
\hline Variables & $\begin{array}{c}\text { Coefficients } \\
\text { Projection I }\end{array}$ & $\begin{array}{c}\text { Coefficients } \\
\text { Projection II }\end{array}$ & $\begin{array}{c}\text { Coefficients } \\
\text { Projection III }\end{array}$ & $\begin{array}{c}\text { Coefficients } \\
\text { Projection IV }\end{array}$ \\
\hline Intercept & 10244.81 & 10869.23 & 11036.65 & 11256.58 \\
& $(5896.32)$ & $(5906.39)$ & $(6196.12)$ & $(6306.89)$ \\
\hline Schooling & 21.72 & 21.72 & 21.72 & 21.72 \\
& $(44.21)$ & $(44.21)$ & $(44.21)$ & $(44.21)$ \\
\hline Temperature summer & $-846.89^{*}$ & $-896.29^{*}$ & $-916.81^{*}$ & $-1023.45^{*}$ \\
& $-(356.41)$ & $-(356.31)$ & $-(386.09)$ & $-(412.11)$ \\
\hline Temperature winter & -2490.83 & -2490.83 & -2490.83 & -2490.83 \\
& $-(2812.35)$ & $-(2812.35)$ & $-(2812.35)$ & $-(2812.35)$ \\
\hline Rainfall winter & 146.04 & 151.23 & 154.36 & 159.63 \\
& $(94.32)$ & $(96.10)$ & $(102.30)$ & $(110.32)$ \\
\hline Rainfall summer & $11.31^{*}$ & $11.31^{*}$ & $11.31^{*}$ & $11.31^{*}$ \\
& $(5.51)$ & $(5.51)$ & $(5.51)$ & $(5.51)$ \\
\hline F- Value & $4.91^{*}$ & $4.91^{*}$ & $4.91^{*}$ & $4.91^{*}$ \\
\hline Adjusted R & 0.20 & 0.20 & 0.20 & 0.20 \\
\hline $\mathrm{N}$ & 254 & 254 & 254 & 254 \\
\hline
\end{tabular}

Note: * Significant at 5 per cent level of significance.

Figures in the parenthesis represent standard errors.

The estimated value of paddy production and the value of estimated future output for farms at plains and farms at hills under four different projections are presented in table 5. The value of output (per hectare) in plains declines in Projection II (US \$720.05), Projection III (US \$757.10) and Projection IV (US \$679.95) when compared to the base category of projection I (US \$800.32). Further, the estimated value of paddy output (per hectare) is too found declining for farms at hills, i.e., Projection II (US
\$437.23), Projection III (US \$456.29) and Projection IV (US \$421.79) when compared to the base category of Projection I (US \$483.87). The table further pinpoints that the paddy output for farms in the plains is expected to decline by 9.97 per cent, 5.40 per cent and 15.04 per cent respectively for Projection II, Projection III and Projection IV, whereas, the loss in paddy production in the farms at hills turned out to be 9.64 per cent, 5.70 per cent and 12.83 per cent in the farms at hills.

Table.5: Production statistics under various projections for paddy farms

(US \$ per hectare)

\begin{tabular}{|l|c|c|c|c|}
\hline Farms & Projection I & Projection II & Projection III & Projection IV \\
\hline Plains & 800.32 & 720.05 & 757.10 & 679.95 \\
& & $-(9.97)$ & $-(5.40)$ & $-(15.04)$ \\
\hline Hills & 483.87 & 437.23 & 456.29 & 421.79 \\
& & $-(9.64)$ & $-(5.70)$ & $-(12.83)$ \\
\hline
\end{tabular}

Note: Figures in parenthesis represent the percentage change as compared to values in Projection I.

Hence, our first maintained hypothesis is rejected because the process of climate change is predicted to reduce the production of paddy crop. Similarly, our second maintained hypothesis is also rejected because the climate change induces more cut in paddy output in farms at plains as compared to farms at Hills. In nutshell, it can be inferred from the table 5 that future decline in paddy output in farms in the plains is more of less similar than that of farms in the hills except for the projection IV thus thereby refutes the myth that the farms with more resources in the plains can cope with the impact of climate change more efficiently than that of farms at hills. Estimation of crop model for wheat farms

The parameter estimates of the crop model in Table 6 for a sample of 400 wheat farms in the hills which again shows that the coefficients for summer temperature and rainfall in both seasons have been found statistically significant at 10 per cent and 5 per cent level of significance in all four projections respectively. Table 7 highlights the parameter estimates of the crop model for a 
sample of 400 wheat farms in the plains and exhibits that the variable schooling is found insignificant in all four projections. Further, it shows that the coefficients for winter temperature and rainfall in both seasons have been found statistically significant at 10 per cent and 5 per cent level of significance in all four projections respectively.

Table.6: Parameter estimates of crop model for wheat for farms in plains

\begin{tabular}{|c|c|c|c|c|}
\hline Variables & $\begin{array}{l}\text { Coefficients } \\
\text { Projection I }\end{array}$ & $\begin{array}{l}\text { Coefficients } \\
\text { Projection II }\end{array}$ & $\begin{array}{c}\text { Coefficients } \\
\text { Projection III }\end{array}$ & $\begin{array}{c}\text { Coefficients } \\
\text { Projection IV }\end{array}$ \\
\hline Intercept & $\begin{array}{c}21273.50 \\
(14562.30)\end{array}$ & $\begin{array}{c}21653.32 \\
(14892.34)\end{array}$ & $\begin{array}{c}22365.28 \\
(15002.89)\end{array}$ & $\begin{array}{l}23569.45 \\
15026.31)\end{array}$ \\
\hline Schooling & $\begin{array}{c}54.48 \\
(39.65)\end{array}$ & $\begin{array}{c}54.48 \\
(39.65)\end{array}$ & $\begin{array}{c}54.48 \\
(39.65)\end{array}$ & $\begin{array}{c}54.48 \\
(39.65)\end{array}$ \\
\hline Temperature summer & $\begin{array}{c}-4533.51 \\
-(3262.01)\end{array}$ & $\begin{array}{c}-4533.51 \\
-(3262.01)\end{array}$ & $\begin{array}{c}-4533.51 \\
-(3262.01)\end{array}$ & $\begin{array}{c}-4533.51 \\
-(3262.01)\end{array}$ \\
\hline Temperature winter & $\begin{array}{c}3270.96 * * \\
(1680.12)\end{array}$ & $\begin{array}{c}3365.39 * * \\
(1698.23)\end{array}$ & $\begin{array}{l}3456.98 * * \\
-(1802.98)\end{array}$ & $\begin{array}{l}3589.36 * * \\
-(1823.21)\end{array}$ \\
\hline Rainfall winter & $\begin{array}{l}7.24 * \\
(1.32)\end{array}$ & $\begin{array}{l}7.24 * \\
(1.32)\end{array}$ & $\begin{array}{l}7.24 * \\
(1.32)\end{array}$ & $\begin{array}{l}7.24 * \\
(1.32)\end{array}$ \\
\hline Rainfall summer & $\begin{array}{l}16.26^{*} \\
(7.41)\end{array}$ & $\begin{array}{l}17.24 * \\
(7.98)\end{array}$ & $\begin{array}{l}17.96^{*} \\
(8.11)\end{array}$ & $\begin{array}{l}18.48^{*} \\
(8.87)\end{array}$ \\
\hline F- Value & $3.47 *$ & $3.47 *$ & $3.47 *$ & $3.47 *$ \\
\hline Adjusted $\mathrm{R}^{2}$ & 0.29 & 0.29 & 0.29 & 0.29 \\
\hline $\mathrm{N}$ & 400 & 400 & 400 & 400 \\
\hline
\end{tabular}

Note: $*$ and $* *$ Significant at 5 and 10 percent level of significance respectively

Figures in the parenthesis represent standard errors.

Table.7: Parameter estimates of crop model for wheat farms for hills

\begin{tabular}{|l|c|c|c|c|}
\hline Variables & $\begin{array}{c}\text { Coefficients } \\
\text { Projection I }\end{array}$ & $\begin{array}{c}\text { Coefficients } \\
\text { Projection II }\end{array}$ & $\begin{array}{c}\text { Coefficients } \\
\text { Projection III }\end{array}$ & $\begin{array}{c}\text { Coefficients } \\
\text { Projection IV }\end{array}$ \\
\hline Intercept & 31191.5 & 32369.21 & 33657.28 & 34560.27 \\
& $(19632.21)$ & $(19862.20)$ & $(20101.52)$ & $(21063.21)$ \\
\hline Schooling & -64.29 & -64.29 & -64.29 & -64.29 \\
& $-(13.56)$ & $-(18.32)$ & $-(19.63)$ & $-(23.40)$ \\
\hline Temperature summer & -21474.82 & -22531.56 & -23658.98 & -24569.21 \\
& $-(13965.21)$ & $-(13865.32)$ & $-(15023.89)$ & $-(15698.02)$ \\
\hline Temperature winter & $1704.56^{* *}$ & $1764.01^{* *}$ & $1824.78^{* *}$ & $1854.06^{* *}$ \\
& $(896.32)$ & $(920.21)$ & $(986.32)$ & $(987.23)$ \\
\hline Rainfall winter & $18.88^{*}$ & $18.88^{*}$ & $18.88^{*}$ & $18.88^{*}$ \\
& $(8.96)$ & $(8.96)$ & $(8.96)$ & $(8.96)$ \\
\hline Rainfall summer & $6.65^{*}$ & $6.65^{*}$ & $6.65^{*}$ & $6.65^{*}$ \\
& $(3.03)$ & $(3.03)$ & $(3.03)$ & $(3.03)$ \\
\hline F- Value & $11.93^{*}$ & $11.93^{*}$ & $11.93^{*}$ & $11.93^{*}$ \\
\hline Adjusted R & 0.31 & 0.31 & 0.31 & 0.31 \\
\hline $\mathrm{N}$ & 400 & 400 & 400 & 400 \\
\hline
\end{tabular}

Note: $*$ and $* *$ Significant at 5 and 10 percent level of significance respectively.

Figures in the parenthesis represent standard errors

Hence, it follows from table $6 \& 7$, that winter temperature and rainfall in both seasons have been found very handy in increasing wheat production for farms in the plains.
The value of wheat production and the value of the estimated value of wheat output for farms plains and hills under four different projections are presented in table 8 . 
Table.8: Production statistics under various projections for wheat Farms

(US \$ per hectare)

\begin{tabular}{|l|c|c|c|c|}
\hline Farms & Projection I & Projection II & Projection III & Projection IV \\
\hline Plains & 822.01 & 756.75 & 782.56 & 738.91 \\
& & $-(7.94)$ & $-(4.80)$ & $-(10.11)$ \\
\hline Hills & 410.36 & 411.47 & 436.79 & 437.85 \\
& & $(0.27)$ & $(6.44)$ & $(6.70)$ \\
\hline
\end{tabular}

Note: Figures in Parenthesis represent the percentage change as compared to values in Projection I.

The value of wheat output (per hectare) in plains declines in Projection II (US \$756.75), Projection III (US \$782.56) and Projection IV (US \$738.91) when compared to the base category of Projection I (US \$822.01). On the contrary, the forecasted value of paddy output (per hectare) for the farm at hills has shown an increasing trend, though marginally, i.e., Projection II (US \$411.47), Projection III (US \$436.79), and Projection IV (US $\$ 437.89$ ) when compared to the base category of projection I (US \$410.36). Table 8 explains the marginal effects of change in temperature and rainfall in farms in the plains and farms in the hills. For farms in the plains, if we consider the Projection II, Projection III and Projection IV, the wheat output is expected to decline by 7.94 per cent, 4.80 per cent, and 10.11 per cent respectively for Projection II, Projection III and Projection IV while for farms at hills it is predicted to increase by 0.27 per cent, 6.44 per cent and 6.70 per cent in farms at hills. Hence, our first maintained hypothesis is rejected in case of wheat crop too, because the process of climate change is predicted to reduce the wheat production. Similarly, our second maintained hypothesis is also rejected because the climate change leads to decline in wheat output in farms at plains and will induce more production of wheat infarms at hills. To sum up, it can be inferred that the decline in paddy output in farms in the hills is substantially less than that of farms in the plains in Projection II and IV thus thereby refuting the myth that the farms with more resources in the plains can better counter the adverse climate conditions.

\section{CONCLUSIONS}

The study appraised the future impact of the climate change on two principal cereal crops by using a crop model in India till 2100 AD. A comparative picture of farms in the plain as well as farms in the hills has also been presented for both crops. The findings pinpoint that the summer temperature and summer rainfall has been found affecting paddy production adversely, whereas winter temperature positively. The winter rain is found supporting wheat production, while the winter temperature poses a deterrent to the same. The findings suggest that the yield of paddy crop is expected to go down by 9.97 percent, 5.40 per cent and 15.04 per cent in the plains, while for the farms in the hills, the paddy production is predicted to go down by 9.64 per cent, 5.70 per cent and 12.83 per cent in the year 2020, 2060 and 2100 respectively. The output of wheat crop is expected to go down by 7.94 percent, 4.80 per cent and 10.11 per cent in the plains, while for farms at hills it set to increase by 0.27 per cent, 6.44 per cent and 6.70 per cent in the year 2020, 2060 and 2100 respectively. Both of our maintained hypotheses have been eliminated because the climate change is found to cause variations in the production of wheat and paddy crops in a differentiated manner for farms in the plains and farms in the hills.

The study urges the expansion of area under wheat cultivation for farms in the hill in order to compensate the loss in yield of wheat farms in the plains that are required for maintaining the aggregate production of wheat at the same level. The study found a dire need to develop temperature resistant, short duration varieties of paddy crop for both farms in the plains and at the hills. The spatial crop diversification (full, partial) is the need of the hour along with the incentives for the farmer to cope up with the future decline in farm production. The predictions made by the study need to be considered with a grain of salt owing to error measurement of adaptations by farmers and carbon fertilisation as well as noninclusion and non-availability of many climatic variables. Moreover, the wheat and paddy crop pertains to C3 varieties which are slightly more resilient to change in temperature and rainfall as compared to other categories of crops. The future research should put more focus on appraising the impact of climate change on all crops using more climate indicators with and without adaptations for longitudinal data besides developing the crop response functions to climate change for livestock production and other crops.

\section{REFERENCES}

[1] Adams, Richard M., D. Glyer, and Bruce A. McCarl, 1989, "The Economic Effects of Climate Change in U.S. Agriculture: A Preliminary Assessment", In D. Tirpak and J. Smith, (eds.), 'The Potential Effects of Global Climate Change on the United States: Report to Congress' EPA 230-05-89-050, Washington, D. C: United States. 
[2] Chang, C.C., 2003, "The Potential Impact of Climate Change on Taiwan's Agriculture", Agricultural Economics, 27(1), pp. 51-64.

[3] Darwin, Roy, Marinos Taigas, Jan Lewandrowski, and Anton Ranees, 1995, "World Agriculture and Climate Change: Economic Adaptations", Agricultural Economic Report 703, U.S. Department of Agriculture, Economic Research Service, Washington, D C.

[4] Economic Survey, 2007-08-2014-15, Oxford University Press, Government of India, New Delhi.

[5] Environmental Protection Agency (EPA), 1994, "The Potential Effects of Global Climate Change on the United States", Washington, D.C.

[6] IPCC, 1996, "Impacts, Adaptations, and Mitigation of Climate Change: Scientific-Technical Analyses"” Contribution of Working Group II to the IPCC Second Assessment Report Cambridge, U.K. Cambridge University Press.

[7] IPCC, 2007, "Summary for Policy-makers. Climate Change 2007: The Physical Science Basis", Working Group I Contribution to IPCC Fourth Assessment Report: Climate Change, Geneva.

[8] Kaiser, H. M., S. J. Riha, D. S. Wilks, D. G. Rossiter, and R. Sampath, 1993, "A Farm Level Analysis of Economic and Agronomic Impacts of Gradual Warming", American Journal of Agricultural Economics 75 (2), pp. 387-398.

[9] Kumar, K. S. Kavi and Jyoti Parikh, 1998. "Climate Change Impacts on Indian Agriculture: The Ricadian Approach". In Dinar, Ariel, Robert Mendelsohn, R. Evanson, 'Measuring the impact of climate change on Indian agricultural', World Bank Technical Paper No. 402, Washington, D.C.

[10] Mendelsohn, R., Nordhaus, W. D. and Shaw, D., 1994, "The Impact of Global Warming on Agriculture", American Economic Review, 84, pp. 753-71.

[11] Mendelssohn, Robert, Ariel Dinar, and Aura Sanghi, 2001, "The Effect of Development on the Climate Sensitivity of Agriculture", Environment and Development Economics, 6, pp. 85-101.

[12] Murdiyarso, Daniel, 2000, "Adaptations to Climatic Variability and Change: Asian Perspectives on Agriculture and Food Security", Environmental Monitoring and Assessment 61(1), pp. 123-131.

[13] Newman, 1980, "Climate change impacts on the growing season of the North American Corn Belt", Biometeorology, 7 (2), pp.128-142.

[14] Parry M. 1., T.R. Knoijin, 1988, "The Impact of Climatic Variations on Agriculture", Kluwer: Dordrecht.
[15] Reilly, John, 1996, "Climate Change and Agriculture - Research Findings and Policy Considerations". In Nurul Islam, (Eds.), 'Population and food in the early twenty-first century: Meeting the future food demand of an increasing population', Washington, D.C.: IFPRI (International Food Policy Research Institute).

[16] Rosenzweig, and Daniel Hillel, 1995, "Potential Impacts of Climate Change on Agriculture and Food Supply", Consequences, 1 (2), pp. 257-292.

[17] Rosenzweig, C., and M. L. Parry, 1994, "Potential Impacts of Climate Change on World Food Supply", Nature, 367, pp. 133-138.

[18] Rosenzweig, Cynthia, 1985, "Potential CO2-Induced Effects on North American Wheat Producing Regions", Climatic Change, 7, pp. 367-389.

[19] Singh, Surender, 2006, "Kyoto Protocol: Toothless and Obsolete", Punjab University Research Journal (Arts), Chandigarh, India. 38(2), pp. 33-42.

[20] Singh, Surender, 2017, "Climate Change and Indian Agriculture: An Assessment of Principal Food Crops", Interdisciplinary Journal of Economics and Business Law, 6(2), pp. 31-47.

[21] Sinha, S.K. and Swaminathan, M.S., 1991, "Deforestation, climate change and sustainable nutrition security: a case study of India", Climatic Change, 19, pp. 201-209.

[22] WBGU (German Advisory Council on Global Change), 2003, "Charging the Use of Global Commons", Special Report, Berlin. 